\title{
各種食品添加物と共存する亜硝酸塩の 比色定量法について
}

(昭和 42 年 9 月 29 日受理)

\section{永 田 致 治* 安 藤 則 秀*}

\section{A Colorimetric Method for the Determination of Nitrite Coexisting with Various Food Additives}

\author{
Yukiharu NAGATA and Norihide ANDO \\ (Faculty of Agriculture, Kyushu University: \\ Hakozaki, Fukuoka)
}

For the purpose of devising a colorimetric method for estimating the accurate amount of nitrite coexisting with various food additives, studies on a modified colorimetric method of Follett and Ratcliff have been made, and the following successful method has been developed in the present work.

Since it has been found that reducing substances and hexametaphosphate interfere with the modified method of Follett and Ratcliff, potassium ferricyanide was added first to a model system containing nitrite and various food additives in order to oxidize the reducing substances.

Potassium ferrocyanide formed by the reaction of potassium ferricyanide with reducing substances interfered with the modified method too, lead acetate, therefore, was added to precipitate it, whereupon hexametaphosphate was also precipitated by lead acetate simultaneously.

By filtering off these precipitates, the filtrate came to be absolutely free from interfering substances, and accordingly the accurate amount of nitrite coexisting with various food additives could be estimated by determining the nitrite in the filtrate following the modified method of Follett and Ratcliff.

(Received September 29, 1967)

肉製品中の亜硝酸塩の量を正確に定量することは，最 近各種食品添加物の使用により複雑となってきた肉製品 の発色機構を追究してゆくためにも，また食品衛生上の 立場からむきわめて重要である.

われわれはさきに，覀硝酸塩と還元型 ascorbate（以 下 R-As と略記）が共存する場合には, 従来用いられて いる比色法または滴定法では，両成分の正しい定量值が 得られないことを明らかにし，水溶液 model system 中 に共存する亜硝酸塩と R-As の両成分を，同時にしかも 正確に定量しらるポーラログラフ法を考案し, さらにこ の定量法を用いて，共存するこの両成分が，保存や加熱 処理の際にどのような挙動を示すかについて追究した結 果を報告した1)2)。

しかしこのポーラログラフによる亜硝酸塩定量法は， 肉加工の際使用される多くの食品添加物によって阻害作
用を受けるため，これらの食品添加物が共存する場合の 悪硝酸塩の挙動は, この方法では正しく追究できないこ とが明らかとなっだ2.

そこで今回, 亜硝酸塩の比色定量法について種々検討 を行ない, 各種食品添加物と共存する亜硝酸塩の量を正 確に定量できる比色定量法を考案することができたの で，その結果について報告する。

\section{実験と考察}

\section{1. 各種比色定量法による亜硝酸塩定量值の比较}

亜硝酸塩の比色定量法は現在までに数多く報告されて いるが，これらのらち通常ひろく使用されている A.O. A.C. 法5), Griess-Irosvay 法617), Shinn 法8) および Follett and Ratcliff 法9)について検討を行なった。

試料溶液は, 前報23) の方法に準じ, pH 5.5 ペロナー ル緩衝液に亜硝酸ナトリウムのみ $0.01 \%$ 含むものと, こ れにアスコルビン酸ナトリウムを $0.1 \%$ 共存させたもの 
Table 1. Effect of Coexisting Reduced Form Ascorbate on the Findings for Sodium Nitrite Determined by Various Colorimetric Methods

[Each sample solution was prepared just before determination by dissolving $0.01 \%$ sodium nitrite and $0.1 \%$ sodium ascorbate in a veronal buffer of $\mathrm{pH} 5.5$ at $0^{\circ} \mathrm{C}$, respectively]

\begin{tabular}{|c|c|c|c|c|c|c|c|c|}
\hline \multicolumn{2}{|c|}{ Concentration in sample solution } & \multicolumn{2}{|c|}{$\mathrm{NaNO}_{2} 0.01 \%$} & \multicolumn{5}{|c|}{$\begin{array}{ll}\mathrm{NaNO}_{2} & 0.01 \% \\
\mathrm{Na} \text {-ascorbate } & 0.1 \%\end{array}$} \\
\hline & Experiment No. & I & II & I & II & III & IV & V \\
\hline \multirow{4}{*}{$\begin{array}{l}\mathrm{NaNO}_{2} \\
\text { found } \\
\text { (ppm) }\end{array}$} & A.O.A.C. method ${ }^{51}$ & 100 & 100 & 26 & 26 & 34 & 35 & 29 \\
\hline & Griess-Irosvay method ${ }^{6 / 7)}$ & 100 & 100 & 92 & 97 & 98 & 98 & 97 \\
\hline & Shinn method ${ }^{8)}$ & 100 & 100 & 39 & 41 & 33 & 43 & 42 \\
\hline & Follett and Ratcliff method ${ }^{91}$ & 100 & 100 & 31 & 31 & 33 & 33 & 34 \\
\hline
\end{tabular}

を、それぞれ $0^{\circ}$ で調製した。

調製直後における各試料溶液中の亜硝酸塩を，上述の 各種比色法で定量した結果は Table 1 のとおりである.

すなわち，R-As を含まない試料溶液では，いずれの 方法によっても亜硝酸塩は正確に定量できたが， R-As が共存する場合には，いずれの方法においてもかなりの 阻害を受けて，亜硝酸塩の定量値は低くなった。 またこ の場合, R-As による阻害の程度は定量法によって著し い差異のあることが認められた。

なお， Follett and Ratcliff 法を用いて調查した Fig. 1 の結果から明らかなよらに, 共存する R-As の濃度を 増すと阻害作用は大となり，西硝酸塩の定量値はしだい に低くなる傾向を示した。

亜硝酸塩を比色定量する際に，共存する R-As が阻害 作用を示す理由は, Table 2 に示すよらに，いずれの比 色法においても，反応液に酶酸や塩酸などを添加し，酸 性域でジアゾ化およびカップリングの反応を行なわせて 発色させるために， R-As が共存すると反応液の $\mathrm{pH}$ p 反応時間などによって著しい影響を受け，ジアゾ化およ びカップリングの反応が進行する際に， R-As による亜 硝酸塩の分解反応も進行するものと考えられる.
以上の結果， R-As のよらな還元性物質が共存する場 合には, 従来の比色法をそのまま適用すると, 亜硝酸塩 の正しい定量値は得られないことが明らかとなった。

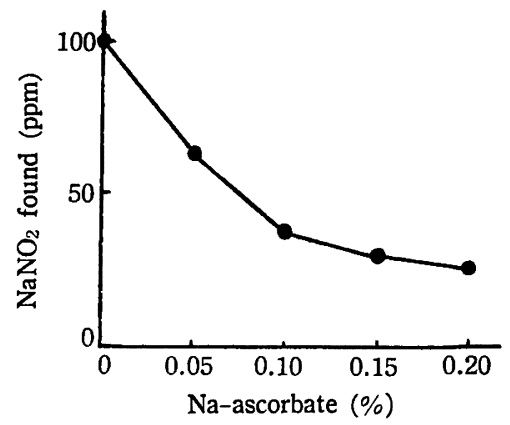

Fig. 1. Effect of coexisting reduced form ascorbate on the findings for sodium nitrite (Modified method of Follett and Ratcliff)

[Each sample solution was prepared just before determination by adding desired amount of sodium ascorbate to a veronal buffer of $\mathrm{pH}$ 7.0 containing $0.01 \%$ sodium nitrite at $0^{\circ} \mathrm{C}$ ]

Table 2. Colorimetric Methods for the Determination of Nitrite

\begin{tabular}{|c|c|c|c|c|c|}
\hline \multirow{2}{*}{ Method } & \multirow{2}{*}{ Color-developing reagent } & \multirow{2}{*}{$\begin{array}{l}\text { Acidifying } \\
\text { reagent }\end{array}$} & \multicolumn{3}{|c|}{$\begin{array}{l}\text { Conditions employed for } \\
\text { color development }\end{array}$} \\
\hline & & & $\mathrm{pH}$ & $\begin{array}{l}\text { Temperature } \\
\left({ }^{\circ} \mathrm{C}\right)\end{array}$ & $\begin{array}{l}\text { Time } \\
(\min )\end{array}$ \\
\hline A.O.A.C. method ${ }^{51}$ & $\begin{array}{l}\text { Sulfanilic acid } \\
\alpha \text {-Naphthylamine }\end{array}$ & Acetic acid & 3.1 & $\begin{array}{l}\text { Room } \\
\text { temperature }\end{array}$ & 60 \\
\hline Griess-Irosvay method ${ }^{(7)}$ ) & $\begin{array}{l}\text { Sulfanilic acid } \\
\alpha-\text { Naphthylamine }\end{array}$ & $\begin{array}{l}\text { Na-acetate } \\
\text { Acetic acid }\end{array}$ & 2.7 & $\begin{array}{l}\text { Room } \\
\text { temperature }\end{array}$ & 10 \\
\hline Shinn method ${ }^{8)}$ & $\begin{array}{l}\text { Sulfanilamide } \\
\text { N-(1-Naphthyl)-ethylene- } \\
\text { diamine dihydrochloride }\end{array}$ & $\begin{array}{l}\text { Hydrochloric } \\
\text { acid }\end{array}$ & 0.8 & $\begin{array}{l}\text { Room } \\
\text { temperature }\end{array}$ & 5 \\
\hline Follett and Ratcliff method ${ }^{9)}$ & $\begin{array}{l}\text { Sulfanilic acid } \\
\alpha-\text { Naphthol }\end{array}$ & $\begin{array}{l}\text { Acetic acid } \\
\text { Ammonia }\end{array}$ & 4.0 & $25 \sim 30$ & 30 \\
\hline
\end{tabular}




\section{2. 実験条件の模討}

（1） R-As による阻害を除去する方法

上述のように，比色法で垔硝酸塩を定量する際，いず れの方法を用いても R-As が共存すると著しく阻害作用 を示すことが明らかとなったので, 亜硝酸塩の比色定量 法のらち最近発表された Follett and Ratcliff 法を選 び,これを改良し正確な亜硝酸塩定量法を確立する目的 でまず R-Asによる阻害を除去する方法について検討 を行なった。

(i) Follett and Ratcliff 変法による亜硝酸塩の定 量：肉製品中の硝酸塩および亜硝酸塩を定量する目的 で, Follett and Ratcliff9!により新しく考案された亜硝 酸塩の比色定量法を，われわれの実験目的に適するよう に一部改変したつぎに示す変法を用いて以下の検討を行 なった.

亜硝酸塩を含む試料溶液 $2 \mathrm{ml}$ を $200 \mathrm{ml}$ 容メスフラ スコにとり, 蒸留水で画線まで満たしたのち, その $5 \mathrm{ml}$ を試験管にとり，これに Orange I 試薬 $5 \mathrm{ml}$ を加えて $30^{\circ}$ の恒温水槽中で 30 分間反応発色させ，流水で 10 分 間冷却後, 得られた発色液について波長 $479 \mathrm{~m} \mu$ に扣け る吸光度を測定する.

この場合使用する Orange I 試薬は, 原法9に準じ， つぎのよらに調製した，すなわち，蒸留水 $360 \mathrm{ml}$ と氷 酢酸 $50 \mathrm{ml}$ を $600 \mathrm{ml}$ 容かっ色試薬ビンにとり, $50^{\circ}$ に 加温したのち，スルファニル酸の粉末 $0.25 \mathrm{~g}$ を加え, 溶けたならばさらに $\alpha$-ナフトール $0.2 \mathrm{~g}$ を加えて溶解 する. 流水で室温まで冷却後, ガラス電極 $\mathrm{pH}$ メーター を用いて，10\%アンモニア水で pH $4.0 \pm 0.05$ に調整し たのち, 蒸留水を加えて全容を $500 \mathrm{ml}$ とする.

な打原法では $\mathrm{pH}$ 9.6 9.7 の $\mathrm{HCl}-\mathrm{NH}_{4} \mathrm{OH}$ 緩衝液を 添加しているが，変法ではこれを添加せず，また原法で は発色の際の温度を $25 \sim 30^{\circ}$ としているが，変法では発 色条件を一定にするために $30^{\circ}$ とし，測定波長も原法で は $474 \mathrm{~m} \mu$ を用いているが，島津製光電分光光度計を使 用して検討した結果，最大吸収波長は $479 \mathrm{~m} \mu$ であった ので,"'変法ではこの波長で比色定量することとした.

(ii) 酸化剂による R-As の阻害除去試験：亜硝酸 塩を比色定量する際に，共存する R-As が阻害作用を示 すのは, 酸性域において R-As が亜硝酸塩を還元して分 解するために起こるのであるから，R-As を酸化して反 応系から除去すれば，その阻害を防止できるであろらと 考えられる。

まず, 強力な酸化剤として, 過マンガン酸カリウムと 臭素について検討を行なったが，これらはいずれも亜硝 酸塩そのものをも分解する作用のあることが認められた ので，この実験目的には使用できなかった。

（iii）覀硝酸塩の比色定量值に及ぼす赤血塩の影響： つぎに，温和な酸化剤であり，タンパク質の $\mathrm{SH}$ 基の定

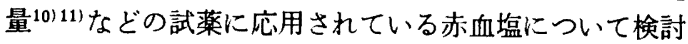

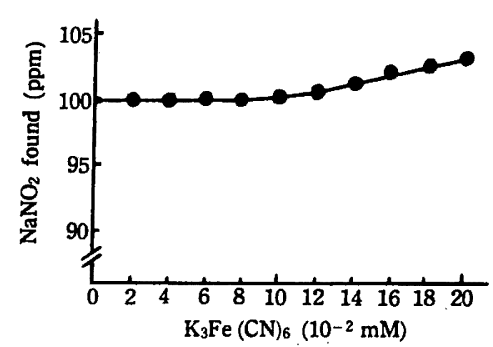

Fig. 2. Effect of potassium ferricyanide on the findings for sodium nitrite

(Modified method of Follett and Ratcliff)

[Each sample solution was prepared just before determination by adding desired amount of potassium ferricyanide to a veronal buffer of $\mathrm{pH} 7.0$ containing $0.01 \%$ sodium nitrite at $\left.0^{\circ} \mathrm{C}\right]$

を行なった，すなわち，覀硝酸ナトリウム $0.01 \%$ と種々 の濃度の赤血塩を含む $\mathrm{pH} 7.0$ ベロナール緩衝液を試料 溶液とし，赤血塩が亜硝酸塩の定量値に及ぼす影響を調 査した。

その結果は Fig. 2 のとおりで, 赤血塩が一定量以上 共存すると, したいに吸光度が增加する傾向を示した が, 発色液の赤血塩濃度 $0.08 \mathrm{mM}$ 以下ではなんら影響 はないことが認められた。

(iv）赤血塩による R-As の阻害除去：上述の結果 を参照し, 赤血塩を用い, 亜硝酸塩と共存する $\mathrm{R}-\mathrm{As}$ を 酸化することによって, R-As による阻害を除去できる かどらかを検討した，すなわち，亜硝酸塩 $0.01 \%$ とも に, アスコルビン酸ナトリウムを $0 \sim 0.2 \%$ 含む $\mathrm{pH} 7.0$ ベロナール緩衝液に, 赤血塩を濃度 $20 \mathrm{mM}$ になるよう に添加し， $0^{\circ}$ で 30 分間保持して R-Asを酸化し，つぎ に比色定量の際の発色液の赤血塩の 終濃度が $0.08 \mathrm{mM}$ 以下になるように蒸留水で希釈してから, 各試料溶液に ついて覀硝酸塩を定量した。

このような定量条件を採用したのは，つぎの理由によ

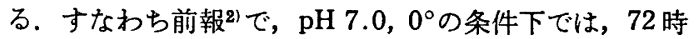
間後においても, 共存する亜硝酸塩と R-As の両成分は 全く反応せず安定であることが明らかにされており，ま た今回，赤血塩による R-As の酸化反応は， $\mathrm{pH} 7.0,0^{\circ}$ の条件下で数分間以内に完結することが確かめられたの

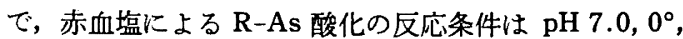
30分間と定めた。 また，発色液の赤血塩終濃度を 0.08 $\mathrm{mM}$ 以下になるように希釈した理由は，(iii)に示したと おりである.

結果はFig. 3 のと扣りで, Fig. 1 に示した赤血塩未 処理の場合ほど著しくはないが， R-As が共存すると， 赤血塩処理を施しても，やはり定量操作中に亜硝酸塩の 一部が分解し，そのため亜硝酸塩の正確な定量値の得ら 


\begin{tabular}{|c|c|c|c|c|c|}
\hline Sample No. & (C) & (1) & (2) & (3) & (4) \\
\hline $\mathrm{NaNO}_{2}$ & 0.01 & 0.01 & 0.01 & 0.01 & 0.01 \\
\hline $\mathrm{Na-ascorbate}(\%)$ & 一 & 0.05 & 0.10 & 0.15 & 0.20 \\
\hline $\mathrm{K}_{3} \mathrm{Fe}(\mathrm{CN})_{6} \quad(\mathrm{mM})$ & - & 20 & 20 & 20 & 20 \\
\hline
\end{tabular}

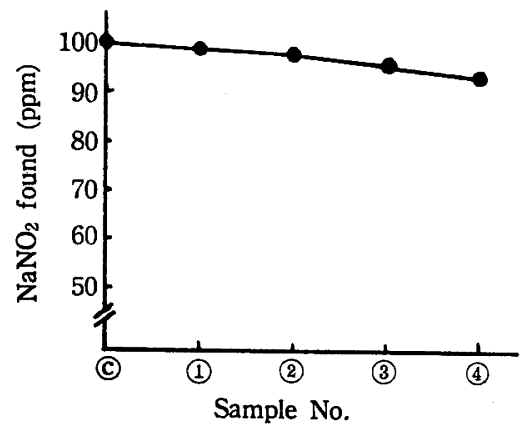

Fig. 3. Effect of potassium ferricyanide on the findings for sodium nitrite coexisting with reduced form ascorbate

(Modified method of Follett and Ratcliff)

[Each sample solution was prepared just before determination by adding desired amount of sodium ascorbate to a veronal buffer of $\mathrm{pH}$ 7.0 containing sodium nitrite and potassium ferricyanide at a concentration of $0.01 \%$ and $20 \mathrm{mM}$ respectively, and allowed to stand for $30 \mathrm{~min}$ at $0^{\circ} \mathrm{C}$ ]

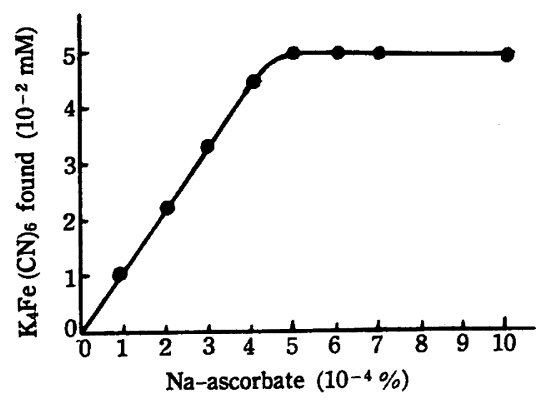

Fig. 4. Formation of potassium ferrocyanide by the reaction of potassium ferricyanide with reduced form ascorbate

¿Each sample solution was prepared just before determination by adding desired amount of sodium ascorbate to a veronal buffer of $\mathrm{pH}$ 7.0 containing potassium ferricyanide at a concentration of $0.05 \mathrm{mM}$, and allowed to stand for $30 \mathrm{~min}$ at $0^{\circ} \mathrm{C}$. Ferrocyanide was determined by the method of Anson and Mirsky ${ }^{9}$ ]
れないことが明らかとなった。この結果から，R-As は 赤血塩によって酸化されるが，それと同時に赤血塩は還 元されて黄血塩となり，これが亜硝酸塩を分解するので はないかと考られる.

（v） 赤血塩と R-As の反応による黄血塩の生成: この推定のように, 果して赤血塩による R-As の酸化に 伴い黄血塩が生成されるかどうかを調べるために, 赤血 塩濃度 $0.05 \mathrm{mM}$, アスコルビン酸ナトリウム濃度 0 $0.001 \%$ の $\mathrm{pH} 7.0$ ベロナール緩衝液を $0^{\circ}$ で調製し， $0^{\circ}$ で 30 分間反応後における各試験液中の黄血塩生成量を Anson and Mirsky の方法10)により定量した。

その結果は Fig. 4 のと拈りで, 赤血塩と R-As の反 応は化学量論的に進行し, 用いた実験条件下では, 赤血 塩 2 モルと R-As 1 モルから黄血塩 2 モルが生成される ことが確かめられた。

（vi） 赤血塩溶液の添加量：試料溶液の R-As 濃度 が, 通常肉加工に使用される程度の量, すなわちアスコ ルビン酸ナトリウムとして $0.1 \%$ (約 $5 \mathrm{mM}$ 溶液に相当) であると仮定すると，この試料溶液 $2 \mathrm{ml}$ 中の R-As を 酸化するには, 前項で述べた実験結果から，10 mM 赤 血塩水溶液 $2 \mathrm{ml}$ を必要とするが, 還元性物質含量の変 動を考虑して幾分過剩に, しかも発色阻害を示さない量 として, 試料溶液 $2 \mathrm{ml}$ に対して $10 \mathrm{mM}$ 赤血塩溶液を $3 \mathrm{ml}$ 添加することとした.

しかしながら, 試料溶液にかなり多量の還元性物質が 含まれ，そのためにこの赤血塩添加量で不足する場合も 考えられる.このような場合には, 赤血塩溶液の示寸黄 色がただちに消失してほとんど無色となるが，これは肉 眼的に容易に観察できるので，そのときはさらに $3 \mathrm{ml}$ の $10 \mathrm{mM}$ 赤血塩溶液を追加する必要がある.

試料溶液中に含まれる還元性物質の量が，アスコルビ ン酸ナトリウムの $0.15 \%$ 相当量以下であれば, 試料溶液 $2 \mathrm{ml}$ に対して $10 \mathrm{mM}$ 赤血塩溶液 $3 \mathrm{ml}$ を添加すると反 応液中に過剩に残存する赤血塩はそのまま発色液に移行 するが，試料溶液の 200 倍希釈液に相当する 発色液の 赤血塩濃度は, 共存する還元性物質の量に応じて 0.075 $\mathrm{mM}$ 以下となり，したがって，Fig. 2 に示した実験結果 から明らかなように，亜硝酸塩を Follett and Ratcliff 変法により比色定量する際に赤血塩が発色阻害を起こす 心配はない。

（vii）亜硝酸塩の比色定量値に及ぼす黄血塩の影響： 亜硝酸塩を Follett and Ratcliff 変法により比色定量す る際に，共存する黄血塩が影響を及ぼすかどうかを調査 するために，亜硝酸塩濃度 $0.01 \%$ ，黄血塩濃度 $0 \sim 20$ $\mathrm{mM}$ の $\mathrm{pH} 7.0$ ベロナール緩衝液を $0^{\circ}$ で調製し, これ らの試料溶液について調製直後に扣ける亜硝酸塩を比色 定量した。

その結果は Fig. 5 に示すとおりで, 前述の亜硝酸塩 と共存する R-As を赤血塩で酸化した場合の定量結果 


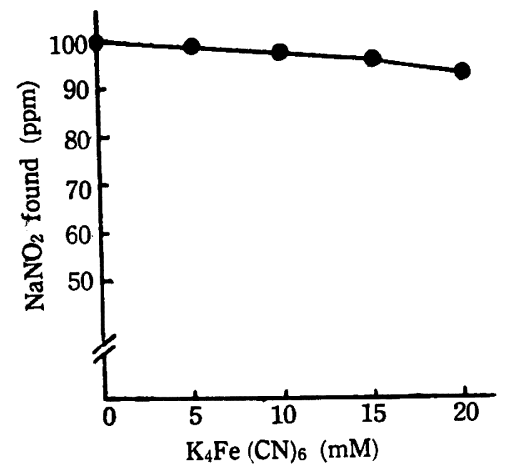

Fig. 5. Effect of potassium ferrocyanide on the findings for sodium nitrite

(Modified method of Follett and Ratcliff)

[Each sample solution was prepared just before determination by adding desired amount of potassium ferrocyanide to a veronal buffer of $\mathrm{pH} 7.0$ containing $0.01 \%$ sodium nitrite at $0^{\circ} \mathrm{C}$ ]

(Fig. 3) と同様の傾向を示し，共存する黄血塩の量にほ ぼ比例して覀硝酸塩の一部が定量操作中に分解すること が認められた。

以上のことから，亜硝酸塩を定量する際，共存する R-As によって生ずる阻害を除く目的で赤血塩処理を行 なっても， R-As と赤血塩の反応の結果生じた黄血塩が 覀硝酸塩を一部分解することが明らかになったので，つ ぎにこの黄血塩を反応系から除去する方法について検討 を行なった。

（viii）反応系よりの黄血塩除去法：黄血塩を反応系 から沈段除去する目的で, 沈殿剂として, 硫酸亜鉛およ び酢酸鉛を選び検討を行なったが，硫酸亜鉛を用いる と, Follett and Ratcliff 変法による业硝酸塩定量の 際, 微量の赤血塩の共存により発色を阻害し白濁を生ず るため，硫酸覀鉛はこの実験目的に使用できなかった。 そこでつぎに酢酸鉛を用いて検討を行なった。

（ix）亚硝酸塩定量值に及ぼす酢酸鉛の影響：使用 する $0.1 \mathrm{M}$ 酢酸鉛溶液は，つぎの方法で調製した。すな わち，炭酸ガスによる白濁を防ぐため，酢酸鉛を煮沸蒸 留水に溶解し，10\%酢酸水溶液で pH 5.5 に調整し定容 としたのち，東洋口紙 No. 6 でろ過する。

この $0.1 \mathrm{M}$ 酢酸鉛溶夜を $0 \sim 20 \mathrm{ml}$ 添加し, 全容を $200 \mathrm{ml}$ とした亜硝酸塩 $2 \mathrm{ppm}$ を含む $\mathrm{pH} 7.0$ ベロナー ル楥衝液を試料溶液とし, 酢酸鉛が Follett and Ratcliff 変法による亜硝酸塩の比色定量值に及ぼす影響を調査し たところ，この試料溶液 $200 \mathrm{ml}$ 中に $0.1 \mathrm{M}$ 酢酸鉛溶 液が $20 \mathrm{ml}$ まで含まれても，亜硝酸塩の定量值になんら 阻害を示さないことが認められた。

（x）酢酸鉛溶液の添加量の検討：西硝酸塩 と共存
する R-As を赤血塩を用いて酸化し，その結果生じた黄 血塩を沈殿除去させるために，酢酸鉛溶液をどの程度添 加すれば R-Asによる阻害を除去できるかについて検討 を行なった、すなわち，あらかじめ $0^{\circ}$ に氷冷した $\mathrm{pH}$ 7.0 ベロナール緩衝液 $25 \mathrm{ml} *, 10 \mathrm{mM}$ 赤血塩水溶液 3 $\mathrm{ml}$, 蒸留水 $25 \mathrm{ml}$ を $200 \mathrm{ml}$ 容メスフラスコにとり,こ れに試料溶液として $0.01 \%$ 西硝酸ナトリウム水溶液扣 よび $0.1 \%$ アスコルビン酸ナトリウム水溶液をそれぞれ $2 \mathrm{ml}$ ずつ添加してよく摫拌混合後, 30 分間氷水中で $0^{\circ}$ に保った。つぎに $0.1 \mathrm{M}$ 酢酸鉛溶液を最高 $20 \mathrm{ml}$ まで 種々の量を加えて室温で30分間放置後, 蒸留水で画線ま で満たし, 東洋口紙 No. 6 を用いてろ過したのち, ろ 液中の亜硝酸塩を Follett and Ratcliff 変法で定量し た.

その結果は Fig. 6 のとおりで, 酢酸鉛の添加量を増 すと R-As と赤血塩の反応の結果生じた黄血塩による阻 害作用はしだいに減少しこの場合 $0.1 \mathrm{M}$ 酢酸鉛溶液 $5 \mathrm{ml}$ 以上の添加により覀硝酸塩は $100 \%$ 回収され, 正確 に比色定量できることが明らかとなった。この実験結果 から，0.1 M 酢酸鉛溶液は $10 \mathrm{ml}$ 添加することとした.

別途実験により，黄血塩と酢酸鉛はそれぞれ $2: 3$ の モル比で反応し，不溶性の錯塩を生成することが確かめ られたが，Fig. 6 に示す実験結果から酢酸鉛はかなり

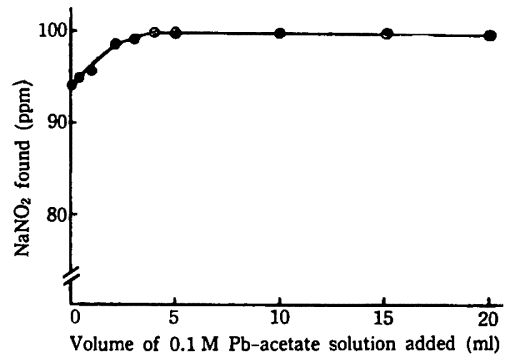

Fig. 6. Effect of lead acetate on the findings for sodium nitrite

(Modified method of Follett and Ratcliff)

[To $25 \mathrm{ml}$ of veronal buffer of $\mathrm{pH} 7.0,2 \mathrm{ml}$ of $0.01 \%$ sodium nitrite solution, $2 \mathrm{ml}$ of $0.1 \%$ sodium ascorbate solution, $3 \mathrm{ml}$ of $10 \mathrm{mM} \mathrm{K}_{3} \mathrm{Fe}$ $(\mathrm{CN})_{6}$ solution and $25 \mathrm{ml}$ of distilled water were added, and the solution was allowed to stand for $30 \mathrm{~min}$ at $0^{\circ} \mathrm{C}$. To which varying volumes of $0.1 \mathrm{M}$ lead acetate solution were added, and the resulting mixture was allowed to stand for $10 \mathrm{~min}$ at a room temperature, then diluted to $200 \mathrm{ml}$ and filtered. Nitrite in the filtrate was determined colorimetrically]

* $\mathrm{pH} 7.0$ ペロナール緩街液を $25 \mathrm{ml}$ 添加することに より, 赤血塩処理反応液を $\mathrm{pH} 7$ に保持し5ること を確かめた。 
過剩に加える必要があり, 0.1 M 酢酸鉛溶液を $10 \mathrm{ml}$ 添 加した場合は, 理論量の䄪30倍も過剰に添加したことに なる.

なお゙赤血塩と酢酸鉛は，この実験条件下では反応しな いことが確かめられた。 また上述の実験において，亜硝 酸塩を比色定量する場合, Shinn 法8) を用いて同様の検 討を行なってみたが，赤血塩や酢酸鉛の添加によりかな りの発色阻害を起こすことが認められた．したがって亜 硝酸塩の比色定量法としては, Follett and Ratcliff 変 法が最も適当であると考えられる.

(xi) 亜硝酸塩の濃度と吸光度との 関係: 上述の検 討により得られた方法を用い， R-As $0.1 \%$ と種々の濃 度の亜硝酸塩を含む $\mathrm{pH} 7.0$ ベロナール緩衝液を試料溶 液として, 悪硝酸塩濃度と発色液の吸光度との関係を調 查した結果, 亜硝酸ナトリウム $0.04 \%$ 以内で覀硝酸塩濃 度と $479 \mathrm{~m} \mu$ における吸光度との間に直線関係が得ら れ，Beer の法則に従うことが認められた。

(xii) R-As と共存する 覀硝酸塩の回収率：われわ れの考案した亜硝酸塩定量法によって, 悪硝酸塩と共存 する R-As の阻害作用が完全に除去できるかどうかをさ らに確認するために, 試料溶液として亜硝酸ナトリウム $0.01 \%$ なびにアスコルビン酸ナトリウム $0.1 \%$ を含む pH 5.0，6.0および 7.0 のベロナール緩衝液を $0^{\circ}$ で調製 し，ただちに亜硝酸塩を定量した.

その結果は Table 3 に示すように, R-As の阻害作 用は，赤血塩および酢酸鉛処理を行ならこの改良法によ って完全に除去され，前報2)のポーラログラフ法による 定量値とほとんど一致して亜硝酸塩は $100 \%$ 回収され, この改良法により R-As が共存する場合にも正確な亜硝 酸塩の定量值の得られることが明らかとなった。

（2）各種食品添加物の影響

垔硝酸塩を定量する場合，上述のように R-Asによる 阻害を除去する改良法を考案することができたが，肉加
工の際使用される R-As 以外のいろいろな食品添加物が 共存する場合, この改良法に対して阻害作用を示すか否 かを確かめるため, Follett and Ratcliff 変法そのもの と，これに赤血塩および酢酸鉛処理を施したた改良法を 対比しながらさらに検討を行なった，使用した食品添加 物の種類は Table 4 のとおりで，普通肉加工の際に使 用される程度の量を用いて実験を行なった。なおこの場 合の各供試液の $\mathrm{pH}$ は 6.0 , 亜硝酸ナトリウム濃度は $0.01 \%$ とし, 使用した食品添加物のらち, システインの 影響をみるために用いたシステイン塩酸塩, およびリン 酸塩類，ソルビン酸とその塩類は，あらかじめ $1 \mathrm{~N}$ と $0.1 \mathrm{~N}$ の水酸化ナトリウムあるいは塩酸溶液で $\mathrm{pH} 6.0$ に調整して使用した。

Table 4 は, 亜硝酸塩の定量值に及ぼす各種食品添 加物の影響を調査した結果を示すもので， Follett and Ratcliff 変法そのものでは, R-As と同様にイソアスコ ルビン酸ナトリウム, システインによる著しい阻害がみ られ，またそのほかにへキサメタリン酸塩がわずかでは あるが阻害を示すことが認められた。 しかし改良法で は，供試した各種食品添加物はすべてなんら阻害を示さ ないことが認められた。このように改良法においては, イソアスコルビン酸ナトリウムとシステインによる阻害 が認められなくなったのは，R-As の場合と同様に，い ずれも赤血塩ならびに酢酸鉛による処理でこれらの成分 が反応系から除去できたことを示している。 またへキサ メタリン酸塩による阻害が除かれたのは, 試薬として加 えた酶酸鉛が，へキサメタリン酸塩と反応して沈殿除去 されたためであることが，別途実験により明らかとなっ た.

\section{3. 実験方法}

上述のようにして実験条件を種々検討の結果, 比色法 により通常肉加工の際に使用される各種食品添加物が共 存しても，西硝酸塩を正確に定量できるつぎのような方

Table 3. Effect of Coexisting Reduced Form Ascorbate on the Findings for Sodium Nitrite Determined by the Modified and Modified and Improved Colorimetric Methods of Follett and Ratcliff, and the Modified Polarographic Method

[Each sample solution was prepared just before determination by dissolving $0.01 \%$ sodium nitrite and $0.1 \%$ sodium ascorbate in a veronal buffer of $\mathrm{pH} 5.0 \sim 7.0$ at $0^{\circ} \mathrm{C}$, respectively]

\begin{tabular}{|c|c|c|c|c|}
\hline \multirow{2}{*}{\multicolumn{2}{|c|}{ Method }} & \multicolumn{3}{|c|}{$\mathrm{NaNO}_{2}$ found (ppm) } \\
\hline & & $\mathrm{pH} 5.0$ & $\mathrm{pH} 6.0$ & $\mathrm{pH} 7.0$ \\
\hline \multirow{2}{*}{$\begin{array}{l}\text { Colorimetric method } \\
\text { of } \\
\text { Follett and Ratcliff }\end{array}$} & Modified & 36.6 & 36.6 & 35.9 \\
\hline & $\begin{array}{c}\text { Modified } \\
\text { and improveda) }\end{array}$ & 99.6 & 99.8 & 99.8 \\
\hline \multicolumn{2}{|c|}{ Modified polarographic method ${ }^{2}$} & 99.7 & 100.0 & 100.0 \\
\hline
\end{tabular}

a) Subjected to the preliminary treatments with $\mathrm{K}_{8} \mathrm{Fe}(\mathrm{CN})_{6}$ and $\mathrm{Pb}$-acetate reagents 
Table 4. Effects of Coexisting Food Additives on the Findings for Sodium Nitrite Determined by the Modified and Modified and Improved Methods of Follett and Ratcliff

[Each sample solution was prepared just before determination by adding desired amount of each food additive to a veronal buffer of $\mathrm{pH} 6.0$ containing $0.01 \%$ sodium nitrite]

\begin{tabular}{|c|c|c|c|}
\hline \multirow{2}{*}{ Additive } & \multirow{2}{*}{$\begin{array}{c}\text { Concentration } \\
\text { in } \\
\text { sample solution } \\
(\%)\end{array}$} & \multicolumn{2}{|c|}{$\mathrm{NaNO}_{2}$ found (ppm) } \\
\hline & & Modified method & $\begin{array}{c}\text { Modified and } \\
\text { improved method }\end{array}$ \\
\hline $\mathrm{NaCl}$ & 2.0 & 100 & 100 \\
\hline $\mathrm{KNO}_{3}$ & 0.1 & 100 & 100 \\
\hline $\mathrm{Na}$-ascorbate & 0.1 & 50 & 100 \\
\hline $\mathrm{Na}$-isoascorbate & 0.1 & 50 & 100 \\
\hline Cysteine & 0.1 & 72 & 100 \\
\hline Nicotinamide & 0.1 & 100 & 100 \\
\hline $\mathrm{NaH}_{2} \mathrm{PO}_{4}$ & 0.5 & 100 & 100 \\
\hline $\mathrm{Na}_{2} \mathrm{HPO}_{4}$ & 0.5 & 100 & 100 \\
\hline $\mathrm{Na}_{8} \mathrm{PO}_{4}$ & 0.5 & 100 & 100 \\
\hline $\mathrm{Na}_{2} \mathrm{H}_{2} \mathrm{P}_{2} \mathrm{O}_{7}$ & 0.5 & 100 & 100 \\
\hline $\mathrm{Na}_{4} \mathrm{P}_{2} \mathrm{O}_{7}$ & 0.5 & 100 & 100 \\
\hline $\mathrm{Na}_{5} \mathrm{P}_{8} \mathrm{O}_{10}$ & 0.5 & 100 & 100 \\
\hline $\mathrm{Na}_{6} \mathrm{P}_{6} \mathrm{O}_{18}$ & 0.5 & 97 & 100 \\
\hline Sorbic acid & 0.1 & 100 & 100 \\
\hline K-sorbate & 0.1 & 100 & 100 \\
\hline Na-sorbate & 0.1 & 100 & 100 \\
\hline $\mathrm{AF}-2^{*}$ & 0.025 & 100 & 100 \\
\hline
\end{tabular}

* A mixture of 1 part of AF-2 and 49 parts of soluble starch. Accordingly, the sample solution contains $5 \mathrm{ppm}$ of $\mathrm{AF}-2$

法を考案することができた.

実験方法：あらかじめ $0^{\circ} に$ 水冷した $\mathrm{pH} 7.0$ ベロナ 一ル緩衝液 $25 \mathrm{ml}, 10 \mathrm{mM}$ 赤血塩水溶液 $3 \mathrm{ml}$ および蒸 留水 $25 \mathrm{ml}$ を $200 \mathrm{ml}$ 容メスフラスコにとり,これに0.04 $\%$ 以下の亜硝酸ナトリウムと, 通常肉加工の際使用され る程度の濃度に各種食品添加物を含む試料溶液を $2 \mathrm{ml}$ 添加し， 30 分間水水中で $0^{\circ}$ に保持する．つぎに $0.1 \mathrm{M}$ 酢酸鉛溶液 $10 \mathrm{ml}$ を添加して室温で 10 分間放置後, 蒸 留水で画線まで満たし, 東洋口紙 No. 6 を用いてろ過 する，万液 $5 \mathrm{ml}$ を試験管にとり，これに Orange I 試

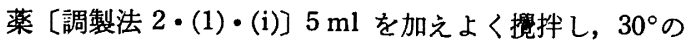
恒温水槽中で 30 分間発色させたのち, 流水で 10 分間冷 却し, 波長 $479 \mathrm{~m} \mu$ における吸光度を 測定する. その 際, 試料溶液を入れないで同様に処理したものを盲検と する.この吸光度の値から，標準液で作成した検量曲線 により亜硝酸塩量を算出する.

なお,この model system における亜硝酸塩定量法 を，肉製品の場合に適用するため，種々検討を行なった 結果, 一応の成果が得られたので，これについては近く 発表の予定である.

\section{要 約}

各種食品添加物と共存する亜硝酸塩を正確に定量で きる比色法を見いだすため， model system を用い， Follett and Ratcliff 変法について種々検討を行なった 結果, この目的にそうつぎのような方法を考案すること ができた.

Follett and Ratcliff 変法で亜硝酸塩を比色定量する 場合, 還元性物質とへキサメタリン酸塩が阻害を示すこ とを認めたので，まず亜硝酸塩と各種食品添加物を含む model system に赤血塩を加えて還元性物質を酸化す る. 赤血塩と還元性物質の反応で生じた黄血塩もまた阻 害を示すので, これを沈殿除去するため酢酸鉛を加える と,この際同時にへキサメタリン酸塩が沈殿する.

これらの沈殿をろ過すると, すべての阻害物質が除去 されるので, このろ液について Follett and Ratcliff 変 法で亜硝酸塩を比色定量すると, 各種食品添加物と共存 する覀硝酸塩の量を正確に定量することができる.

終わりに本研究を行ならにあたり, 実験にご協力下さ った重副由紀子嬢と坂口恵子竓に深く感謝の意を表しま 
す.

本報の要旨は昭和 39 年度日本畜産学会大会（昭和 39 年 4 月，東京）飞批いて発表.

文献

1) N. Ando, Y. Kako, Y. Nagata: Bull. Meat and Meat Products 2, 7 (1963).

2) 永田致治, 安藤則秀: 栄圽と食糧 19, 424 (196667).

3）永田致治，安藤則秀：同上 19, 282 (1966).

4) 水田致治, 安藤則秀: 同上 19, 286 (1966).

5) Methods of Analysis, A.O.A.C. 389 (1955).
6) R. Novak, P. W. Wilson: J. Bacteriol. 55, 517 (1948).

7) 山田敏郎, 江上不二夫ほか編：“標準生化学実験” p. 348 (1953) 文光堂, 東京.

8) M. B. Shinn: Ind. Eng. Chem., Anal. Ed. 13, 33 (1941).

9) M. J. Follett, P. W. Ratcliff: J. Sci. Food Agr. 14, 138 (1963).

10) M. L. Anson, A. E. Mirsky: J. Gen. Physiol. 24, 679 (1941).

11) A. Kajita: J. Biochem. (Tokyo) 26, 547 (1954). 